\title{
Approach to Identify Internal Best Practices in a Software Organization*
}

Calvo-Manzano Jose A. ', Cuevas Gonzalo', Mejia Jezreel ', Muñoz Mirna San Feliu Tomás ${ }^{3}$, Sánchez Ángel ${ }^{2}$, and Rocha Álvaro ${ }^{3}$

${ }^{1}$ Universidad Politécrica de Madrid.

Facultad de Informática Campus de Montegancedo $\$ / N$, 28660 Madrid, Spain \{joseantonio. calvomanzano, gonzalo. cuevas, ma muroz

tomas.sanfeliu\} êpm.es, jmejialempsej.fi.upm.es

${ }^{2}$ Everis foundation, Av Manoteras 52, 28050 Madrid. España

Angel. Sanchezleveris.com

${ }^{3}$ Universidade Fernando Pessoa, Praça 9 de Abril, 349, 4249-004 Oporto, Portugal amrochadupf .edu.pt

Abstract. Cuirent approaches to software process improvements (SPT) In software organizations is based on identifying gaps by comparing the way organizations work with respect to practices contained in the reference models. Later, these gaps will be targeted for establishing software process improvements. This paper presents an approach for identifying best practices within the orgarization. This is considered a key elernent in order to compare the within the orgarization. This is considered a key elernent in order to compare the
way software organizations work with the reference models. After that, these practices will be complemented with practices contained in these nodels depending on the organization's business goals.

Keywords: best practices, software process improvement, software organizations, knowledge management, change management.

\section{Introduction}

In order to be a successful organization, it is necessary to have the skills to create strategic advantages with respect to its competitors. To achieve this, the organization should be able to create knowledge in order to maximize their competitiveness and to develop a successful strategy [1].

In this context, organizations should have mechanisms to create knowledge and manage it as an asset. The amotnt of knowledge in an organization is amazing [2] However to be useful, knowledge must be shared and increased within the organization [1], [3]

Respect to these two aspects, best practices have been recognized as building blocks of organizational leaming and organizational knowledge [4]. Therefore, using best practices in organizations is an approach to help organizations to create and share their knowledge.

Authors listed by organization. 
Unfortunately, identifying best practices in organizations becomes a big problem as a result of organizations spending considerable resources developing processes that: are inefficient, do not reflect the business needs, and are foreign wo those who use them [5].The reason is that organizations do not know best practices.

The goal of this paper is to present a method that allows the organization to dentify internal best practices. The best practices identified will allow organizations: 1) To keep up key knowledge within the organization and 2) To understand the way the organization works. This will allow them to have a solid baselinstand the way strengths when developing a software process improvement initiative.

In this context, improving the organizational process will allow organizations to achieve a competitive advantage respect to its competitors.

This paper is structured as follows: section two shows the backoround; section three introduces the benefits and current problems of the best practices used in organizations: section four presents the method for identifying best practices in an organization; section five shows the experimentation of the method and finally, section six presents the conclusions.

\section{Background}

In this section the concepts in which the method is based are described.

\subsection{Knowledge}

Knowledge is the information that each person, group of people or organizations has. So. it involves the use of information and data as well as the skills, competencies, ideas, commitments and motivation of those people. In other words, knowledge is information in action [1], [3].

Due to the dynamic nature of knowledge, organizations are always experimenting a cycle of creation and learning between the two kinds of knowledge that exists: racit knowledge and explicit knowledge [1], [2]

- Tacit knowledge: This is personal knowledge. This kind of knowledge is within people's mind as a result of their experience. It involves intangible factors such as personal beliefs, perspectives, and underlying values. However, most of the time people are not aware of what they know and, therefore, it is difficilt to share.

- Explicit knowledge: This is highly codified knowledge. This kind of knowledge is expressed as information contained in databases and documents. So, it is more easily transmitted and managed. However, in order to be applied it requires a process of adoption by people.

\subsection{Knowledge Management}

On the one hand, knowledge management (KM) is a systematic approach to facilitate the flow of data. information and knowledge to the right people at the right time, so they can act more efficientiy and effectively ['6].
On the other hand, $\mathrm{KM}$ allows the capture, codification, use and exploitation of knowledge and experiences to develop better tools and methods, as well as to develop a willingness and ability to use these methods [4]. However. KM reguires an organizational effort to build, operate, maintain, and spread a knowledge-sharing environment.

In this context, knowledge management is important because it helps organization in generating value and building a competitive edge, because the organization by itself will be able to retrieve and understand the structured and unstructured data convert data into useful information, and share the knowledge [7].

\subsection{Change Management}

Nowadays change is inevitable in all environments such as socio-cultural, political economic and business. For this reason organizations have recognized that the refinement and application of business processes is the key to survival. Therefore, the process must be managed as part of core business [8].

Besides, it is necessary to take into account the scope of changes, their competition with other changes and the speed of change, which can overwhelm the organization, destroy its investment and generate a barrier to change [7], [9].

Therefore, change management is the process of planning, organizing, coordinating and controlling internal and external components in order to ensire that process changes are implemented with the minimum deviation compared to the approved plans [7].

\subsection{Best Practices}

A best practice could be a management or technical practice that has consistently demonstrated to improve one or more aspects such as productivity, cost. schedule. and quality or user satisfaction [10].

Due to the importance of best practices, relevant institutions such as the Software Engineering Institute (SEI), the Project Management Institute (PMI), the Institute of Electrical and Electronics Engineers (IEEE), and the International Organization for Standardization (ISO) have been focused on the study of best practices. They lrave developed best practices reference models and standards [1I].

The most widespread models and standards developed are: Capability Maturity Model and Integration for Development (CMMI-DEV) [12]; Team Software Process (TSP) [13]; Project Management Body of Knowledge (PMBOK)[14]; ISO/IEC15504 Information technology - Process assessment [15]; ISO 9001:2000- Quatity Management System [16]; ISO/IEC 12207-2008 [17]

\section{Benefits and Current Problems of Using Best Practices in Software Organizations}

Best practices are considered the core of organizational learning and organizationa knowledge [4]. Unfortunately, best practices could be harmful if they are used improperIy in combination with others practices or in a wrong situation. That is why it is important to know benefits and cument problems of best practices. 


\subsection{Benetits}

The benefit of best practices is that their introduction in organizations is a ke element for improving their quality and productivity [18]

Best practices lise a bottom-up approach to software process improvement which consists in identifying the internal best practices in an organization and promoting
their use [19].

This approach reinforces the organization's learning by documenting practices knowledge is preserved and promoting their use so that the key organizational organization to improve its processenitted [20]. Besides, best practices allow the

\subsection{Current Problems}

Even when a wide variety of models and standards have been developed, it should take into account that best practices that work in an organization's environment won't
necessarily work in another one [20].

In this context, Daxid West [21] highlights that the current problem in organizations is the identification of its best practices, which is becoming one of the
main challenges facing the new process generation.

This problem is reinforced in OSD [22], where it is mentioned that best practices can go unnoticed in an organization for years, and even, once they are known, more than two years can go by before their active adoption by the staff across all units of

Besides, Szulaski [22] has identified three obstacles when adopting best practices in an organization: 1) the lack of motivation for adopting the practices, 2) the lack of information for adopting and making them work and, 3) the lack of assimilation capacity due to himited resources and knowledge management skills.

These obstacles are often reflected in organizations, due to the lack of skills for identifying and transmitting best practices in orgarizations, and thus making necessary to resolve a problem, which has already been solved in one unit, in others [2].

Regarding the problem of identifying organizations best practices, aporoaches [2]. as those proposed by Herron and Garmus [23] and Shull and Turner [24] have been developed. However, these approaches have the problem of increasing staff resistance to collaborate in the identification of best practices, because the request of quantitative data is perceived by staff as a threat to their work

\section{A Method for Identifying Best Practices in Software \\ Organizations}

In order to develop the proposed method for identifying internal best practices, some of the principles of knowledge management and change management have been taken into account. Both are considered key elements for successful identification of internal best practices.
Knowledge management: allows the capture, codification, use and exploitation of the knowledge and experiences to develop better tools and methods, as weli as to develop a willingness and ability to use these methods.

- Change management: allows to plan, organize, coordinate and control the internal components to ensure that there are no deviations or change resistance during the identification process of the organization's best practices.

Figure 1 shows a general scheme of the proposed method and how it maiches with knowledge management (KM) and Change management (ChM).

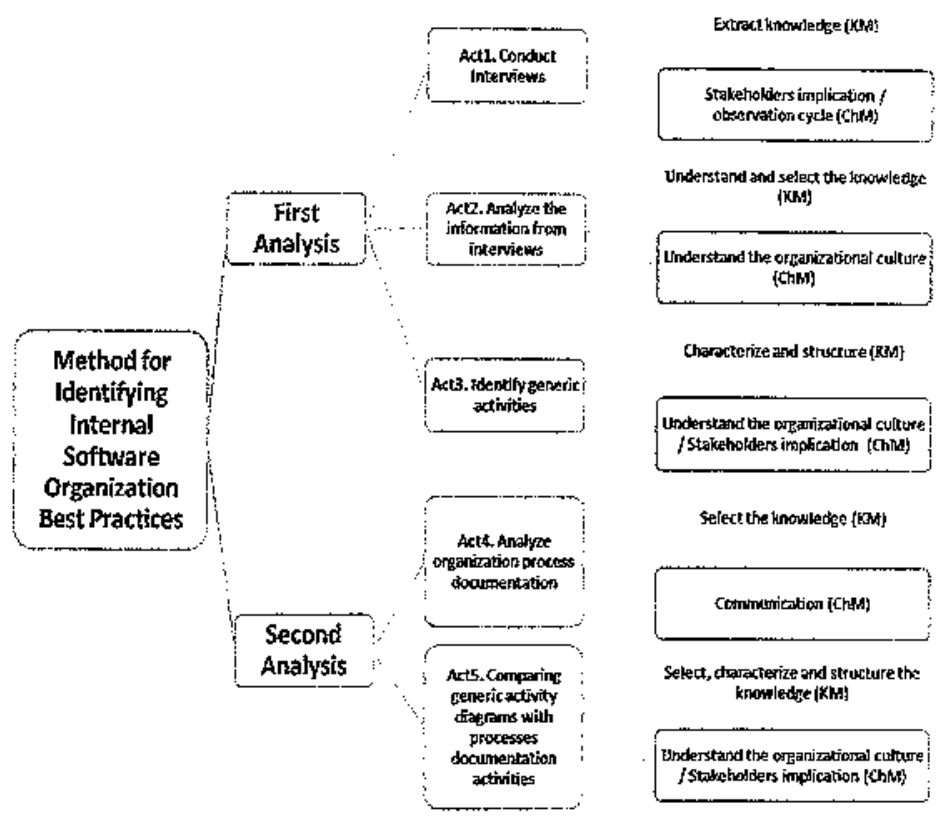

Fig. 1. Method for identifying organizations best practices

As Figure 1 shows, the method contains two analyses and five activities that are warned out to identify an organization's best practices. The analyses allow to maintain a steady involvement of the staff, where:

- The first analysis contains three activities and is focused on the extraction of tacit nowledge from accoun managers who have developed projects considered as successful. In this work, a project is considered successful when the performance reloted to predictability, operational effectiveness, productivity, quality and user satisfaction is high. Therefore, it has the knowledge of the practices that best work in the organization. 
- The second analysis contains two activities and is focused on analyzing an organization's processes documentation in order to know what practices are documented. Then, it maps current practices performed in the organization and documented process practices.

By carrying out both analyses, it is possible to identify the organization's best practices. During the analyses an observation cycle was also carried out. The observation cycle was defined to support the change management. As Figure 2 shows, the observation cycle contains three activities: 1) observe behavior, 2) describe and classify behavior, and 3) identify risks.

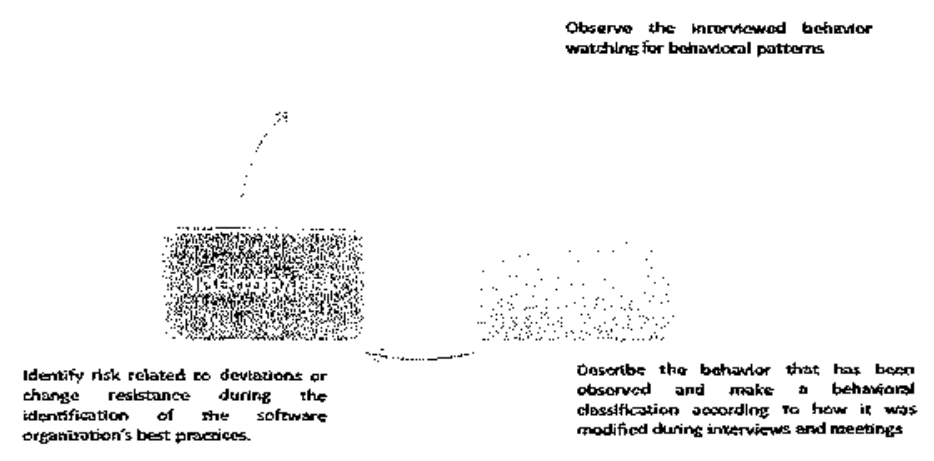

Fig. 2. Observation cycle activities

\subsection{First Analysis}

In this analysis knowledge management is critical because all the organization's tacit knowledge is extracted and documented. In order to achieve this extraction a codified approach of knowledge management is used. The codified approach is focused on the reuse of the organization's key knowledge. It relies on the efficiency of reuse and reduction in work and communication costs [25]

This approach allows to coliect the best practices the account managers, selected by senior management carried out as "suppliers of success cases". Having identified the organization's best practices, the reuse of the organization's key knowledge is enabled.

The firsi analysis activities are structured in a way that knowledge can be: I) extracted, 2) understood and selected, and 3) characterized and stractured. The activities of the first analysis are:

\subsubsection{Conduct Interviews}

The purpose of this activity is to extract the tacit knowledge of the organization's staff. To achieve this, the account managers who have managed projects considered as successful are interviewed. On the one hand, these account managers have been previously selected by senior management. On the other hand, interviews are semistructured that are recorded and questionnaires are used as a guide. Table l shows the subactivities for this activity.
Table 1. Subactivities of the activity Conduct interviews

\begin{tabular}{ll}
\hline Activities & Description \\
\hline Develop a questionnaire & $\begin{array}{l}\text { Develop a questionnaire which should have open questions and } \\
\text { contain easily understood questions. So. it will allow to collect } \\
\text { infornation from the activities carried out by the interviewee in a } \\
\text { free and open way. }\end{array}$ \\
Plan interviews & $\begin{array}{l}\text { Plan interviews as closely as possible according to the number of } \\
\text { meeetings the account managers agteed on. } \\
\text { Interview each account manager. }\end{array}$ \\
\hline Interviews &
\end{tabular}

\subsubsection{Analyze the Information from the Interviews}

The purpose of this activity is to analyze the information gathered from previots interviews and then to make activity diagrams for each interview. The activity diagrams show the activities that each interviewee carries ort to achieve a specific task.

Once the activity diagrams are made, they must be approved by the respective account manager interviewed. This action allows to verify that the activity diagrams faithfully represent the activities the interviewee carried ont for a specific task. Table 2 shows the subactivities for this activity.

Table 2. Subactivities of the activity Analyze the information from interviews

\begin{tabular}{|c|c|}
\hline Activities & Description \\
\hline Identify activities & $\begin{array}{l}\text { Analyze data from each interview in order to identify activities. } \\
\text { Besides, other information such as inpur information, rools, } \\
\text { techniques, and obtained work products could be ifentifijed. }\end{array}$ \\
\hline Make activity diagrams & $\begin{array}{l}\text { Make diagrams with the information identified from intervews. } \\
\text { In this activity the organization's key knowledge is documenred. }\end{array}$ \\
\hline $\begin{array}{l}\text { Approve activity diagrams with } \\
\text { interviewees }\end{array}$ & $\begin{array}{l}\text { Have meetings with the interviewed account managers in order to } \\
\text { receive feedback and approval of the activity diagrams. These } \\
\text { approval meetings will ensure thar activity diagrams reflect the } \\
\text { curregt activities done by the account managers interviewed. }\end{array}$ \\
\hline
\end{tabular}

\subsubsection{Identify Generic Activitie}

The purpose of this activity is to compare all the activity diagrams the account managers approved in order to get a set of common activities called "generic activities". Table 3 shows the subactivities of this activity.

After comparing all the activity diagrams, terms must be unifted. This unification will allow to select the word that will be better understood by the organization's staff. Then, generic activity diagrams are made.

This activity should finish with all the activity diagrams reviewed and approved by account managers, project managers and project leaders. This way of review assures that all the organization is using the same language, so the generic practices will be understood across the organization. 
Table 3. Subactivities of the activity: Identify generic activities

\begin{tabular}{ll}
\hline Activities & Description \\
\hline Compare all activity diagrams & $\begin{array}{l}\text { Compare all activity diagrams in order to identify a common } \\
\text { activities name as generic activities. }\end{array}$ \\
Develop a dictionary of terms & $\begin{array}{l}\text { Develop a glossary which lists the words that describe a specific } \\
\text { activity. Each term contains a description, synonyms and related } \\
\text { activities. }\end{array}$ \\
Unify the name of the activities & $\begin{array}{l}\text { Select the word that best describe an activity of the list of words } \\
\text { (including synonyms and related activities) from the glossary. }\end{array}$ \\
Make generic activity diagrams & $\begin{array}{l}\text { Make diagrams trom the set of common activities identified. } \\
\text { Besides, the seguence of the activities is established. }\end{array}$ \\
Approve generic activity & $\begin{array}{l}\text { Approve the generic activity diagrams at three levels: account } \\
\text { managers, project managers and project leaders because they } \\
\text { diagrams } \\
\text { represent the real organization process and must be understood by }\end{array}$ \\
\hline
\end{tabular}

\subsection{Second Analysis}

The second analysis first analyzes the organization's processes documentation to identify the practices that should be carried out in the organization; and then makes a mapping between generic activity diagrams and the documented practices.

As a result the actual organization's intemal practices will be identified. Furthermore, these practices will become the organization's best practices. Next, the activities that comprise the second analysis are described.

\subsubsection{Analyze Organization Process Documentation}

The purpose of this activity is to collect and analyze the organization's processes documentation. Moreover, the analysis carried out in this activity will help to identify the lack of the organization's processes docurfentation. Table 4 shows the subactivities.

Table 4. Subactivities: Analyze organization processes documentation

\begin{tabular}{ll}
\hline Activities & Description \\
\hline $\begin{array}{l}\text { Collect the organization's } \\
\text { processes documentation }\end{array}$ & Reguest and collect the organization's processes documentation. \\
Analyze the organization's & $\begin{array}{l}\text { Analyze the organization's processes documencation to identify } \\
\text { what activities are documented. } \\
\text { processes documentation } \\
\text { Make a list of the organization's processes documentation with } \\
\text { the findings. This list will help to improve the organization's } \\
\text { processes documentation so that it will be in accordance to the } \\
\text { actual activities carried out in the organization. }\end{array}$ \\
\hline
\end{tabular}

\subsubsection{Comparing Generic Activity Diagrams with Processes Documentation} Activities

The purpose is to map generic activity diagrams (obtained from the first analysis) and the activities contained in the organization's processes documentation.
The mapping purpose is to identify the documented practices that are really carried out in the organization. Then, the dictionary of terms should be updated to unify the activities name.

Finally, the activity diagrams which contain the current organization activities are made. The practices contained in these diagrams become the organization's internal best practices. Table 5 shows the subactivities.

Table 5. Subactivities: Comparing generic activity diagrams with processes documentation activities

\begin{tabular}{|c|c|}
\hline Activities & Description \\
\hline $\begin{array}{l}\text { Compare generic activity } \\
\text { diagrams with the processes } \\
\text { documentation }\end{array}$ & $\begin{array}{l}\text { Compare the generic activity diagrams with the processes } \\
\text { documentation. This accivity will help to identify which activities } \\
\text { should be included in the organization's processes } \\
\text { documentation, so that they reflect the way the organization } \\
\text { works. }\end{array}$ \\
\hline Update dictionary of terms & $\begin{array}{l}\text { Update the dictionary of terms so that it allows the setection of } \\
\text { the word that best describes an activity. Therefore. the seketed } \\
\text { word will be understood and used by the staff. }\end{array}$ \\
\hline Unify the name of the activities & $\begin{array}{l}\text { Unifying the name of the activities will allow the staff actoss the } \\
\text { organization to speak the same langtage in a process context. }\end{array}$ \\
\hline Make real activity diagrans & $\begin{array}{l}\text { Make diagrams with the set of the actual of ganzzation's accivities } \\
\text { within the organization. It will become the organization's internal } \\
\text { best practices. }\end{array}$ \\
\hline Approve activity diagrams & $\begin{array}{l}\text { Approve the activity diagrams at three levels: account managers. } \\
\text { project managers and project leaders. The generic activity } \\
\text { diagrams should be approved in this way as they represent the } \\
\text { organization's best practices. }\end{array}$ \\
\hline
\end{tabular}

\section{Case Study}

This section presents the experimentation of the method camied out in everis in order to identify its project management best practices.

Everis is a multinational consulting firm with factories in Europe and Latin America. It offers services which provide solutions to large companies in any sector and it is based on three pillars: innovation, methodologies and efficiency. Since its creation in 1996, it has grown both in revenue and staff in a steady and organic way. Turnover in 2008 was over $300 \mathrm{M} E$ and the company employs more than 6,000 people. They have over 1,000 projects open every month.

Before the method was tested, it was validated by the delivery management group of everis. This validation was done through meetings with the delivery management group. These meetings allowed feedback that was used for improving the activities described in the method.

Once the method was validated, the scope of the experimentation was based on two aspects:

- Process: The experimentation of the method is focused in everis' project management processes because project management has a broad impact on the organization's business goals. 
- Staff: The experimentation of the method focused on project management was projects). by account managers because they manage projects (heading one or more the feedback of best project managers and project leaders have a significant role in the feedback of best practices identification and validation.

Figure 3 shows the intemal best practices identification carried out in everis.

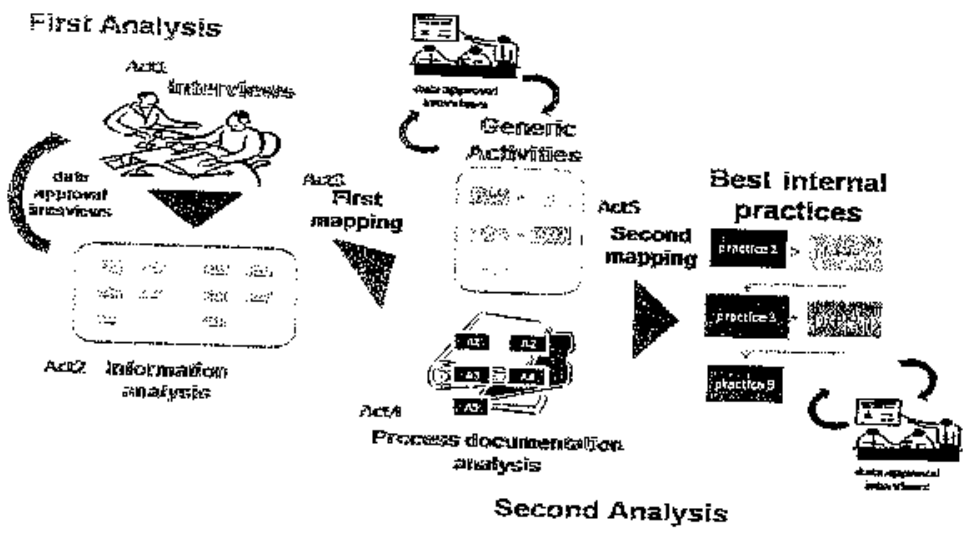

Fig. 3. Everis project management best practices identification

Figure 3 shows the activities carried out in everis. They are as follows:

Actl. Account managers who have managed successful cases were interviewed. The account managers interviewed were chosen previously by senior management

The most representative unit was located in Madrid, so the interviews were Iimited to the account managers from Madrid.

Act2. Information gathered from previous interviews was analyzed. Then, activity diagrams for each interview were obtained, Later, meetings with account managers were carried out repeatedly until the activity diagrams were approved.

Act3. The activities of all the approved diagrams were mapped in order to get a common set of activities called "generic activities". After the generic activities were identified, the generic activity diagrams were obtained diagrams were approved at three levels: project leaders project me generic activity managers.

Act4. The organization's processes documentation was analyzed to identify the activities contained in the processes documentation.

Act5. The generic activity diagrams with the activities of the organization's processes documentation diagrams were mapped. It allowed everis to identify internal bes practices. Then, internal best practices were approved at the three levels: project leaders, project managers and accoint managers.
It is important to highlight that best practices at everis, identified by the method, are the result of the first phase of the methodology for the implementation of software process improvements. The results of the improvement have showed that the identified organization best practices allowed a baseline containing the strengths of the organization to carry out a successful implementation of software process improvement in project management processes at everis [7]. Table 6 shows the improvement results summary related to use and usefulness of new processes.

Table 6. Improvement results summary

\begin{tabular}{lcc}
\hline Indicator & Before (2007) & After (2008) \\
\hline Process acceptance (use) & I0\% & $31 \%$ \\
Process acceptance (usefulness) & $10 \%$ & $95 \%$ \\
\hline
\end{tabular}

\section{Conclusions}

Involving relevant stakeholders in the identification of organizations internai bes practices has allowed the extraction, collection and formalization of the organization's tacit knowledge.

The extracted knowledge has been formalized through processes which reflect the work being performed in the organization. Moreover, these processes are written in a language that is familiar to the organization's staff.

Likewise, beginning a software process improvement by identifying the organization's internal best practices allows the tailoring of models to the business organizations needs because the working culture is known.

Therefore, new processes which are more effective and better accepted by seatr are obtained, and staff perceives the adoption of the practices as a continuous evolution of the way they work.

Acknowledgements. This work is sponsored by everis Foundation and Polytechnical University of Madrid through the Software Process Intprovement Research Group for Spain and Latin American Region.

\section{References}

1. Gupta, J., Sharma, S., Hsu, J.: An overview of knowledge management, ch. 1. Idea Group Inc., USA (2004)

2. Molina J.L., Marsal, M.: La gestión del conocimiento en las organizaciones. VI Hertamientas de la gestión del conocimiento, IX gestión del cambio, pp. $60-68,87-94$ (2002)

3. Turban, E., Aronson, J.E., Liang, T.-P.: Knowledge Management. In: Decision Suppon Systems and Intelligent Systems, ch. 9, p. 487. Prentice Hall, Uppers Saddle Rjver (2005)

4. Williams, $T$ : How Do Organizations Lean Lessons From Projects-And Do They? I1Eet Transactions on Engineening Management 55, 248-266 (2008)

5. CMMT Working group: The Economics of CMMT@, NDIA Systerns Engineering Division. v $1.0(2009)$ 
6. Burke, G., Howard. W: Knowledge Management and Process Improvement: an Union of Two Disciplines. CrossTalk (June 2005)

7. Calvo-Manzano, J.A., Cuevas, G., Gomez, G., Mejia, J., Muñoz, M., San Feliu, $\mathbf{T}$. Sanchez, A.: Methodology for Process Irnprovement through Basic Components and Focusing on the Resistance to Change. In: EuroSPI 2009 Industrial Proceedings (2009) ISBN 978-87-7398-151-1

8. Nilajan. S., Mousumi, B.: Managing Change in Organizations. Prentice-Harl of India Private Limited, New Delhi (2006)

9. Calvo-Manzano, J.A.. Cuevas, G., Muñoz, M., San Feliu. T.: Process Similarity Study; Case Study on Project Planning Practices Based on CMMI-DEV v1.2. In: EuroSPI 2008 Industrial Proceedings (2008) ISBN 978-87-7398-150-4

10. Withers, D.H.: Software engineering best practices applied to the modeling process. In: Simulation Conference Proceedings, vol. I, pp. 432-439 (Winter 2000)

11. Brotbeck, G., Miller, I. Statz, J.: A survey of Current Best Practices and Utilization of Standards in the Public and Private Secrors. Ir: DIR: Department of Information Resources (2006)

12. Chrissis, M.B., Konrad, M., Shrum. S.: CMMO Second Edition Guidelines for Process Integration and Product Improvement, United States, Massachusetts. Addison Weskey, Reading (2007)

I3. Hurnphrey, W.: Introduction to the Team Software Process. Massachusetts, p. 459. Addison-Wesley, Reading (2006)

14. IEEE Computer Society: TEEE Guide Adoption of PMI Standard A Guide to the Project Management Body of Knowledge; IEEE Guide Adoption of PMI Standard A Guide to the

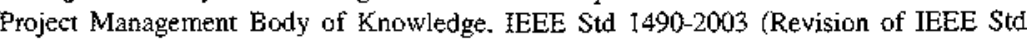
1490-1998), pp. 0_1-216 (2004)

15. International Organization for Standardization: ISOnEC 15504: 2004 Information technology - Process assessment (2004)

16. AENOR: Sistemas de Gestión de Calidad (ISO 9001:2000), UNE-EN ISO 9001, Nomma Española (2000)

17. International Otganization for Standardization: Systems and Software Engineering Software Life Cycle Processes, IEEE STD 12207.2008, IEEexplorer, pp. cl-138 (2008)

18. Beynon. D.R.J.: Interpreting Capability Maturity model Integration (CMMI) for business Development organizations in the Government and Industrial Business Sectors, Tech. Rep. Technical Note CMU/SEI-2007-NT-004 (2007)

19. Gainer, J.: Best Practices: Informal, Effective Process Improvement (2006)

20. OSD Comptroller iCenter: Best Practices \& Benchmarking, Making Worthwhile Comparisons, pp. 9 (2004)

21. David, W.: Enough Process Let's Do Practices: An Introduction to EssWork and EssUP. In: Information Technology (IT) Conference 2007 (2007)

22. Szulanski, G.: The process of knowledge transfer: A diachronic analysis of stickiness. Organ. Behav. Hum. Decis. Process. 82, $9(2000)$

23. Herron, D.. Garmus, D.: Identifying Your Organization's Best Practices. Crosstalk (June 2005)

24. Shull. F., Turner, R.: An empirical approach to best practice identification and selection: the US Department of Defense acquisition best practices clearinghouse. In: International Symposium on Empirical Software Engineering 2005, pp. 8, 17-18 (2005)

25. Mathiassen, L., Pourkomeylian, P.: Managing knowledge in a software organization. Journal of Knowledge Management 7.63 (2003) 